\title{
Alternativas a fungicidas sintéticos no controle da antracnose da banana
}

\author{
Erivanda Silva de Oliveira ${ }^{1}$; Francisco Marto Pinto Viana ${ }^{2}$; Marlon Vagner Valentim Martins ${ }^{3}$.
}

${ }^{1}$ Engenheira Agrônoma, Ms, Universidade Federal do Ceará. ${ }^{2}$ Francisco Marto Pinto Viana, Fitopatologista, D.Sc. - Pesquisador A, Embrapa Agroindústria Tropical-Empresa Brasileira de Pesquisa Agropecuária (Embrapa), Fortaleza/CE. ${ }^{3}$ Marlon Vagner Valentim Martins, Eng. Agr., D.Sc., Pesquisador em Fitopatologia, Embrapa Agroindústria Tropical-Empresa Brasileira de Pesquisa Agropecuária (Embrapa), Fortaleza/CE. Autor para correspondência: Francisco Marto Pinto Viana (marto.viana@embrapa.br)

Data de chegada: 25/04/2014. Aceito para publicação em: 06/10/2015.

$10.1590 / 0100-5405 / 2000$

\section{RESUMO}

Oliveira, E.S.; Viana, F.M.P.; Martins, M.V.V. Alternativas a Fungicidas Sintéticos no Controle da Antracnose da Banana. Summa Phytopathologica, v.42, n.4, p.340-350, 2016.

Dentre as doenças de pós-colheita em banana, a antracnose (Colletotrichum musae), destaca-se entre os mais importantes fatores limitantes da produção no mundo. Com objetivo de controlar esse patógeno, avaliou-se a atividade fungitóxica dos extratos e óleos essenciais de Lippia sidoides Cham., Caryophillus aromaticus L. e Eucalyptus citriodora Hook.; dos antagonistas Trichoderma sp., levedura IA8, e um isolado de Bacillus subtilis; dos indutores de resistência Acibenzolar-S-Metil, fosfito e ácido salicílico e dos produtos antimicrobianos, hipoclorito de sódio, dióxido de cloro e sorbato de potássio, através de ensaios in vitro e in vivo. Os testes in vitro os tratamentos foram incorporados em meio de cultura BDA + tetraciclina $\left(50 \mu \mathrm{g} \cdot \mathrm{mL}^{-1}\right)$, nas concentrações de 5,10 , $15,20,25,30 \%(\mathrm{p} / \mathrm{v})$ de cada extrato bruto; $0,25,50$ e $100 \mu \mathrm{L}$ de cada óleo; $0,05 \mathrm{~g}, 0,3 \mathrm{~g}$ e $300 \mu \mathrm{L}$ dos indutores Acibenzolar-S-Metil, ácido salicílico e fosfito repectivamente, $0,1 \mathrm{~g}, 25 \mathrm{~mL}$ e $100 \mu \mathrm{L}$ dos anti-microbianos, sorbato de potássio, hipoclorito de sódio e dióxido de cloro, respectivamente. A atividade antagônica foi determinada pelo método de culturas pareadas para Trichoderma sp. e pelo método do funil para a levedura IA8, ambos cultivados em placas de Petri contendo meio BDA. B. subtilis (já formulado) foi testado na proporção de $100 \mu \mathrm{L} / 100 \mathrm{~mL}$ de BDA. Placas contendo apenas meio BDA ou o fungicida carbendazim $(10 \mu \mathrm{L} / 100 \mathrm{~mL})$, foram usadas para efeitos comparativos. Todos os tratamentos foram distribuídos em delineamento inteiramente casualizado com cinco repetições cada, incubadas a $28 \pm 2^{\circ} \mathrm{C}$ e fotoperíodo de $12 \mathrm{~h}$ durante sete dias. As médias foram comparadas pelo teste de Tukey a $5 \%$ de probabilidade. Nos testes in vivo foram usadas bananas "Prata" com dois orifícios cada, onde foram depositados $20 \mu \mathrm{L}$ de cada tratamento utilizado in vitro (extratos e óleos essenciais, antagonistas, produtos sanitizantes e indutores de resistência). Doze horas após incubação, as bananas foram inoculadas com $20 \mu \mathrm{L}$ da suspensão de esporos de C. musae $\left(2,7 \times 10^{4}\right.$ conídios $\left./ \mathrm{mL}\right)$ e distribuídos em bandejas plásticas ( 5 bananas/bandeja/tratamento) em delineamento inteiramente casualizado, cada orifício representando uma repetição. Os dados foram submetidos à análise de variância e as médias comparadas pelo teste de Tukey a $5 \%$ de probabilidade. Os resultados in vitro observou-se que os extratos e óleos essenciais de L. sidoides e C. aromaticus, em todas as concentrações testadas, assim como o ácido salicílico e o hipoclorito de sódio foram tão efetivos quanto o controle químico, em inibir o crescimento do patógeno em $100 \%$. O fosfito e os antagonistas Trichoderma $s p$. e $B$. subtilis também exerceram excelente atividade fungitóxica com reduções de 91,$8 ; 84,0$ e 74,0 \% respectivamente. Nos testes in vivo apenas Trichoderma sp e hipoclorito de sódio apresentaram reduções significativas (acima de $50 \%$ ) no desenvolvimento de lesões nas bananas.

Palavras-chave: Colletotricum musae, atividade fungitóxica, antagonismo, pós-colheita.

\section{ABSTRACT}

Oliveira, E.S.; Viana, F.M.P.; Martins, M.V.V. Alternatives to fungicides in the control of banana anthracnose. Summa Phytopathologica, v.42, n.4, p.340-350, 2016.

Of the postharvest banana diseases, anthracnose (Colletotrichum musae), stands out among the most important limiting factors in the world. In order to control this pathogen, we evaluated the fungitoxic activity of extracts and essential oils from Lippia sidoides Cham., Caryophillus aromaticus L. Hook and Eucalyptus citriodora; antagonists Trichoderma sp yeast IA8, and one isolate of Bacillus subtilis; resistance of the inductors Acibenzolar-S-Methyl, salicylic acid and phosphite; and antimicrobial products of sodium hypochlorite, chlorine dioxide, and potassium sorbate, both in vitro and in vivo. In vitro tests were incorporated into treatments through BDA + tetracycline culture $(50 \mu \mathrm{g} . \mathrm{mL}-1)$ at concentrations of $5,10,15,20,25,30 \%(\mathrm{p} / \mathrm{v})$ of each crude extract; $0,25,50$ and $100 \mu \mathrm{L}$ of each oil; $0.05 \mathrm{~g}, 0.3 \mathrm{~g}$ and $300 \mu \mathrm{L}$ of the inductors Acibenzolar-SMethyl, salicylic acid and phosphite respectively; and $0.1 \mathrm{~g}, 25 \mathrm{~mL}$ and $100 \mu \mathrm{L}$ of the antimicrobials potassium sorbate, sodium hypochlorite and chlorine dioxide, respectively. The antagonistic activity was determined by the method of paired cultures for Trichoderma sp. and by the funnel method for IA8 yeast, both cultured in Petri dishes containing BDA medium. B. subtilis (already drawn) was tested at the proportion of $100 \mu \mathrm{L} / 100 \mathrm{~mL}$ of BDA. Plates containing only $\mathrm{BDA}$ and the fungicide carbendazim $(10 \mu \mathrm{L} / 100 \mathrm{~mL})$ were used for comparative purposes. All treatments were distributed in a completely randomized design with five replicates each, and incubated at $28 \pm 2{ }^{\circ} \mathrm{C}$ in a $12 \mathrm{~h}$ photoperiod for seven days. Means were compared by Tukey test at $5 \%$ probability. In vivo tests utilized "Silver" bananas with two holes each, into which were deposited $20 \mu \mathrm{L}$ of each treatment used in vitro (extracts and essential oils, antagonists, sanitizer products and resistance inducers). Twelve hours after incubation, the bananas were inoculated with $20 \mu \mathrm{L}$ of spore suspension of C. musae $\left(2.7 \times 10^{4}\right.$ conidia/ml) and distributed into plastic trays ( 5 bananas / bin / treatment), in a completely randomized design with each hole representing a repetition. Data were subjected to analysis of variance and means were compared by Tukey test at $5 \%$ probability. The in vitro results demonstrated that the essential oils and extracts of $L$. sidoides and C. aromaticus at all concentrations tested, as well as salicylic acid and sodium hypochlorite, were as effective as the chemical control at inhibiting the pathogen growth at $100 \%$. The phosphite and antagonists Trichoderma sp. and B. subtilis also exerted great fungitoxicity with respective reductions of $91.8,84.0$ and $74.0 \%$. In vivo tests only Trichoderma sp and sodium hypochlorite showed significant reductions (over $50 \%$ ) in lesion development in bananas.

Keywords: Colletotrichum musae, fungitoxic activity, antagonism, post-harvest. 
A banana (Musa spp.) está entre as frutas mais consumidas, ocupando mundialmente a segunda posição, com consumo girando em torno de $10 \mathrm{~kg} / \mathrm{hab}$./ano, sendo superada apenas pela laranja. Atualmente, o Brasil se destaca como quinto produtor mundial da fruta, com a produção de 6.978.310 t/ano (18).

São Paulo, Bahia, Santa Catarina, Minas Gerais, Pará, Ceará e Pernambuco são responsáveis por $74 \%$ da produção brasileira. No país, são cultivados pouco mais de 500 mil ha e estima-se que a fruta gere 520 mil empregos diretos e dois milhões indiretos (1).

É uma fruta consumida quase sempre na forma in natura, o que faz dela parte integrante da alimentação da população de baixa renda, não só pelo seu alto valor nutritivo, como também por seu custo relativamente baixo.

Apesar de sua importância, a bananeira, como a maioria das culturas que ocupam grandes áreas, está sujeita a vários problemas fitossanitários, dentre os quais se destaca a antracnose, doença causada pelo fungo Colletotrichum musae (Berk. \& M. A. Curtis) Arx, (1957), de ocorrência em pós-colheita e com ampla distribuição geográfica (48). Frutos com antracnose formam lesões escuras e deprimidas. Com o progresso da doença, estas lesões aumentam de tamanho e podem coalescer.

Economicamente, o patógeno é muito importante porque, além causar prejuízos em pós-colheita, também causa perdas no campo e é fator limitante da qualidade prejudicando a comercialização dos frutos (13). Frutos infectados pelo fungo têm o seu amadurecimento acelerado e, mesmo que a polpa não seja atingida, torna-se de aspecto indesejável para o consumo, tornando-se os frutos com sintomas inviáveis para a exportação (16).

$\mathrm{Na}$ pós-colheita, as medidas de controle são constituídas principalmente de fungicidas. Atualmente, tem sido muito incrementada a utilização de biofungicidas, extratos vegetais e óleos essenciais, tencionando evitar os danos ao homem e ao ambiente causados pelos produtos químicos sintéticos, os quais podem causar fitotoxicidade, ter espectro de ação que resultem em resistência do patógeno e efeitos prejudiciais (7).

Trabalhos desenvolvidos com extratos brutos ou óleos essenciais, obtidos a partir de plantas medicinais, têm indicado o potencial dessas substâncias no controle de fitopatógenos (15). Recentemente, Negreiros et. al. (32) testaram alguns produtos, dentre esses, óleos essenciais para controle da antracnose da banana 'Prata' comparando-os com o efeito do fungicida preconizado (tiabendazol) para tratamento póscolheita, obtendo-se redução da doença e a qualidade dos frutos não foi depreciada.

O controle biológico tem mostrado bons resultados nas doenças pós-colheita (47). A diversidade de microrganismos, bem como suas relações antagônicas, surgem como ferramentas importantes para o controle biológico aplicado. No que se refere a antagonistas bacterianos, há prevalência dos gêneros Pseudomonas (P. putida e P. fluorescens), Bacillus e Streptomyces, representantes da família Enterobacteriaceae (10). O Bacillus spp. se destaca por formar endósporos e apresentar uma multiplicidade de mecanismos antagônicos. Também a produção de antibióticos é característica de algumas leveduras efetivas no controle in vitro e in vivo de doenças (8).

Espécies do gênero Trichoderma encontram-se entre os agentes de biocontrole de doenças mais estudados no mundo, pois não têm se revelado patogênicos. Várias espécies de Trichoderma possuem um arsenal de mecanismos de ação antagônica e produzem substâncias anti-microbianas que garantem um amplo espectro de atividade contra diferentes fitopatógenos, portanto possuem capacidade de controlar várias doenças (27).
Muitas substâncias químicas são capazes de provocar reações de defesa das plantas, como o ácido jasmônico, o ácido salicílico, os salicilatos e os análogos, os silicatos, o fosfito de potássio, a quitosana (6). Em pós-colheita, já existem diversos relatos de sucesso com o emprego de indutores de resistência, os trabalhos realizados mencionam o uso de acibenzolar-S-metil em diferentes plantas para o controle de alguns patógenos (38), como C. gloeosporioides em frutos de mamão $(31 ; 35)$ e no controle da mancha-aquosa em melão, ocasionada pela bactéria Acidovorax avenae subsp. citrulli (40).

Outras técnicas têm sido estudadas buscando-se alternativas limpas para o controle de doenças em pós-colheita de frutos, inclusive produtos químicos já empregados rotineiramente, como os sanitizantes. Alternativas para o uso do hipoclorito vêm sendo estudadas, entre as quais, o dióxido de cloro. Os trabalhos desenvolvidos por Terão et. al. (46) concluíram que o dióxido de cloro, associado à refrigeração, pode contribuir de maneira eficiente no controle integrado de doenças pós-colheita de melão.

Segundo Franco e Bettiol (19), o emprego do conservante alimentar sorbato de potássio na ocorrência de bolor verde $(P$. digitatum) em pós-colheita de citros apresentou uma redução de $67,6 \%$ em frutos de laranja 'Pera'.

Portanto, com o presente trabalho, objetivou-se avaliar a eficiência do emprego de extratos e óleos essenciais vegetais, microrganismos antagonistas, indutores de resistência e sanitizantes em contraste com o fungicida sintético no controle da podridão pós-colheita da banana causada por C. musae.

\section{MATERIAL E MÉTODOS}

Os ensaios foram conduzidos no Laboratório de Micologia e Patologia de Sementes do Departamento de Fitotecnia da Universidade Federal do Ceará em associação com o Laboratório de Fitopatologia da Embrapa Agroindústria Tropical.

\section{Obtenção do isolado de $C$. musae}

$\mathrm{O}$ isolado de C. musae foi obtido a partir de bananas adquiridas em supermercados de Fortaleza, as quais foram selecionadas por exibirem manchas escuras e massa de conídios alaranjadas, sintomas típicos da antracnose. $\mathrm{O}$ isolamento do fungo foi realizado de forma usual conforme Alfenas e Mafia (2).

\section{Verificação in vitro do efeito de extratos e óleos essenciais vegetais sobre Colletotrichum musae}

Os óleos essenciais de alecrim pimenta, cravo-da-índia e eucalipto foram adquiridos de lojas especializadas no comércio de Fortaleza, CE. Os extratos hidroalcóolicos (EHAs) foram preparados a partir de partes de vegetais de espécies apontadas como produtoras de substâncias bioativas, a saber: folhas e galhos secos de alecrim pimenta (Lippia sidoides Cham.); folhas frescas de eucalipto (Eucalyptus citriodora Hook) e botões florais secos de cravo-da-índia (Caryophillus aromaticus L.), obtidos, respectivamente, junto ao Laboratório de Fitoterápicos de Horizonte, CE; Campus do Pici da UFC e Mercado São Sebastião, em Fortaleza, CE. Amostras de cada espécie vegetal foram pesadas, nas proporções de $300 \mathrm{~g}, 195 \mathrm{~g}$ e $1.000 \mathrm{~g}$ para alecrim pimenta, cravo e eucalipto, respectivamente. Cada amostra triturada em liquidificador industrial foi imersa em $1.000 \mathrm{~mL}$ de uma solução hidroalcóolica (1:1 água e etanol) e deixada descansar por 3 dias consecutivos à temperatura ambiente $\left(28^{\circ} \mathrm{C} \pm 2^{\circ} \mathrm{C}\right)$. $\mathrm{O}$ homogenato obtido foi coado em peneira, acondicionado em frasco Erlenmeyer e 
estocado sob refrigeração a $5^{\circ} \mathrm{C}$ até a instalação do experimento. Por ocasião dos testes, os extratos obtidos foram submetidos a evaporadores para eliminação do solvente (etanol) e então incorporados em meio de cultura BDA + tetraciclina $\left(50 \mu \mathrm{g} \cdot \mathrm{mL}^{-1}\right)(\mathrm{BDA}+\mathrm{T})$ nas concentrações de $5 \%, 10 \%, 15 \%, 20 \%, 25 \%$ e $30 \%$ (p/v), e distribuídos em placas de Petri (20mL/placa). Os óleos essenciais foram empregados nas concentrações de $0 \mu \mathrm{L}, 25 \mu \mathrm{L}, 50 \mu \mathrm{L}$ e $100 \mu \mathrm{L}$ por $100 \mathrm{~mL}$ de BDA $+\mathrm{T}$. Um disco ( $5 \mathrm{~mm}$ de diâmetro) de micélio com 7 dias de cultivo foi repicado para o centro das placas contendo os extratos e os óleos essenciais, as quais foram vedadas com parafilme e incubadas a $28^{\circ} \mathrm{C}$ $\pm 2^{\circ} \mathrm{C}$ e fotoperíodo de $12 \mathrm{~h}$ durante 7 dias. Placas de Petri, contendo apenas meio de cultura BDA ou o fungicida carbendazin $(100 \mathrm{~mL}$ p.c./ $100 \mathrm{~L} \mathrm{de}_{2} \mathrm{O}$ ) foram utilizadas como testemunhas absoluta e relativa, respectivamente.

\section{Atividade de microrganismos antagonistas sobre $\boldsymbol{C}$. musae}

Nos ensaios de controle biológico foram empregados três antagonistas, representados por um isolado de Trichoderma sp. (TF1Trichoderma do feijão) e um isolado de levedura (IA8), pertencentes à coleção do Laboratório de Micologia e Patologia de Sementes do CCA/UFC, e um isolado de Bacillus subtilis obtido do Laboratório de Fitopatologia da Embrapa Agroindústria Tropical.

\section{Atividade antagônica de Trichoderma sp. sobre $\boldsymbol{C}$. musae}

O teste foi efetuado em placas de Petri pelo método de pareamento utilizando-se discos de Ágar-água de $5 \mathrm{~mm}$ de diâmetro da colônia de Trichoderma sp. e C. musae com sete dias de idade. Margens das colônias de ambos os fungos foram plaqueadas em meio BDA e em lados opostos da placa de Petri, a $7 \mathrm{~cm}$ entre si. Placas inoculadas somente com discos de C. musae ou Trichoderma sp., pareadas com disco de Ágar, foram empregadas como testemunha. As placas foram incubadas a $28^{\circ} \mathrm{C} \pm 2^{\circ} \mathrm{C}$ e fotoperíodo de $12 \mathrm{~h}$ durante 7 dias. Efetuouse a avaliação por meio da medição (em $\mathrm{cm}$ ) do crescimento linear das colônias de ambos os fungos, observando- se a formação de zona de demarcação entre as colônias, além da sobreposição do antagonista sobre o patógeno e a presença ou ausência de zona de demarcação.

\section{Atividade antagônica da levedura IA8 e Bacillus subtilis sobre C. musae}

As colônias utilizadas para preparo da suspensão da levedura antagonista foram cultivadas em meio seletivo de leveduras YW (3 g de extrato de levedura; $3 \mathrm{~g}$ de extrato de malte; $5 \mathrm{~g}$ de peptona; $10 \mathrm{~g}$ de dextrose; $17 \mathrm{~g}$ de ágar; $1.000 \mathrm{~mL}$ de água destilada) a $28^{\circ} \mathrm{C} \pm 2^{\circ} \mathrm{C}$ e fotoperíodo de $12 \mathrm{~h}$, repicadas 3 vezes consecutivas, a intervalos de 24 h. A partir da última repicagem, obteve-se a suspensão de células, pela adição de $10 \mathrm{~mL}$ de solução salina esterilizada à superfície do meio, efetuando-se a raspagem com auxílio da alça de Drigalski. Após duas diluições consecutivas, obtidas pela transferência de $1 \mathrm{~mL}$ da suspensão original para tubos de ensaio com $9 \mathrm{~mL}$ de solução salina, obteve-se a concentração final $\left(10^{7} \mathrm{ufc} \cdot \mathrm{mL}^{-1}\right)$ usada no ensaio. Neste estudo, empregou-se o método do funil (29), utilizando-se um funil de vidro, com abertura de $7 \mathrm{~cm}$ de diâmetro, o qual teve sua parte mais larga imersa na suspensão da levedura e, em seguida, a suspensão retida nos bordos da boca do funil era transferida para placas de Petri com $9 \mathrm{~cm}$ de diâmetro, contendo meio BDA. A cada imersão do funil na suspensão antagonista, ele foi desinfestado com álcool e então flambado. $\mathrm{O}$ isolado de $B$. subtilis foi adquirido já formulado e pronto para aplicação na dose de $1 \mathrm{~mL} . \mathrm{L}^{-1}$ de $\mathrm{H}_{2} \mathrm{O}$. Para o teste in vitro, utilizou-se $(10 \mu \mathrm{L} B$. subtilis. $100 \mathrm{~mL}^{-1}$ de BDA). As placas da levedura e B. subtilis foram incubadas em sala de crescimento com temperatura de $28^{\circ} \mathrm{C} \pm 2{ }^{\circ} \mathrm{C}$ e fotoperíodo de $12 \mathrm{~h}$. No centro dessas placas, colocou-se um disco de ágar de $5 \mathrm{~mm}$ de diâmetro contendo estruturas de C. musae, obtidos de colônias com 7 dias de idade. No caso da levedura, a inoculação procedeu-se após $24 \mathrm{~h}$. Como testemunhas, utilizaram-se placas de Petri contendo meio BDA, sendo as suspensões da levedura e $B$. subtilis substituídos por solução salina esterilizada. As placas assim preparadas foram incubadas a $28^{\circ} \mathrm{C} \pm r^{\circ} \mathrm{C}$ e fotoperíodo de $12 \mathrm{~h}$ durante 7 dias.

\section{Efeito de indutores de resistência sobre $C$. musae}

Os indutores de resistência testados foram Acibenzolar-S-Metil (BTH ou Bion ${ }^{\circledR}$ ), o fosfito de potássio (FP) e o ácido salicílico (AS). O ASM foi empregado na dose de $0,05 \mathrm{~g}$ do produto comercial, o FP a $300 \mu \mathrm{L}$ e o AS a $0,3 \mathrm{~g}$, todos incorporados a $100 \mathrm{~mL}$ do meio BDA + Tetraciclina, com o meio de cultura ainda fundente. O patógeno $C$. musae foi introduzido na forma de discos de micélio para o centro das placas de Petri contendo o meio de cultura BDA com os indutores, as quais foram incubadas a $28^{\circ} \mathrm{C} \pm 2^{\circ} \mathrm{C}$ e fotoperíodo de $12 \mathrm{~h}$ durante 7 dias.

\section{Efeito de substâncias anti-microbianos sobre $C$. musae}

Foram testadas dois sanitizantes, o dióxido de cloro $\left(\mathrm{ClO}_{2}\right)$ a 1,2 \% i.a., e o hipoclorito de sódio (NaCLO) a 1,5 \% i.a.; e foi empregada uma substância com propriedade anti-fúngica e conservante, o sorbato de potássio $\left(\mathrm{C}_{6} \mathrm{H}_{7} \mathrm{O}_{2} \mathrm{~K}\right)$. As concentrações utilizadas foram de $100 \mu \mathrm{L}$ do $\mathrm{ClO}_{2}, 0,1 \mathrm{~g}$ de $\mathrm{NaCLO}$ e $25 \mathrm{~mL}$ do $\mathrm{C}_{6} \mathrm{H}_{7} \mathrm{O}_{2} \mathrm{~K}$ incorporados a $100 \mathrm{~mL}$ de meio de cultura BDA $+\mathrm{T}$, contido em placas de Petri.

\section{Avaliações e análises estatísticas}

A atividade fungitóxica dos extratos e dos óleos vegetais, dos microrganismos antagonistas, dos indutores de resistência e das substâncias anti-microbianas foram determinadas por meio da medição do diâmetro das colônias do patógeno, 7 dias após instalação do experimento, sendo o percentual de inibição calculado pela seguinte fórmula: \% INIBIÇÃO $=(C 0-C 1)$ X 100/C0, onde C0 é o crescimento da testemunha e $\mathrm{C}$ lé o crescimento do tratamento. Todos os experimentos foram conduzidos em delineamentos inteiramente casualizados com cinco repetições. Cada parcela experimental foi representada por uma placa de Petri. Os dados foram submetidos à análise de variância, e as médias, comparadas pelo teste de Tukey a $5 \%$ de probabilidade, empregando-se o programa ASSISTAT (40).

Efeito de produtos alternativos no controle da podridão póscolheita da banana causada por $C$. musae

Foi avaliada a atividade dos extratos vegetais e óleos essenciais, indutores de resistência e substâncias anti-microbianas, e microrganismos antagonistas, todos testados em ensaio preliminar contra C. musae obtido de banana "Prata". As bananas empregadas no teste foram colhidas no estádio de pré-maturação, com a casca verde amarelada, tendo sido provenientes do Sítio Barreiras, em Missão Velha-CE. Inicialmente, essas bananas foram desinfestados com hipoclorito de sódio $(0,5 \% \mathrm{v} / \mathrm{v}$ do produto comercial $/ 30$ segundos $)$ e depois lavados com água destilada esterilizada por duas vezes consecutivas. Após a secagem natural dos frutos, com auxílio de um furador-de-rolhas, foram efetuados dois orifícios de $5 \mathrm{~mm}$ de diâmetro por $2 \mathrm{~mm}$ de profundidade no mesmo lado dessas bananas (um poço proximal e outro distal) a 5 $\mathrm{cm}$ uma da outra. Em cada orifício foi adicionado $20 \mu \mathrm{L}$ de cada um dos tratamentos nas proporções indicadas na Tabela 1 .

Foram empregados como testemunhas, absoluta e relativa, bananas tratadas com igual volume de água destilada esterilizada e bananas tratadas com o fungicida carbendazin $\left(10 \mu \mathrm{L} .100 \mathrm{~mL}^{-1}\right.$ de $\left.\mathrm{H}_{2} \mathrm{O}\right)$, respectivamente. Essas bananas foram distribuídas diretamente em 
Tabela 1. Tratamentos e concentrações utilizadas nos testes in vivo.

\begin{tabular}{|c|c|}
\hline TRATAMENTO & CONCENTRAÇÃO EMPREGADA \\
\hline \multicolumn{2}{|l|}{ Extrato } \\
\hline Alecrim pimenta & Extrato bruto \\
\hline Cravo-da-índia & Extrato bruto \\
\hline Eucalipto & Extrato bruto \\
\hline \multicolumn{2}{|l|}{ Óleo essencial } \\
\hline Alecrim pimenta & $100 \mu \mathrm{L} / 100 \mathrm{~mL}$ de $\mathrm{H}_{2} \mathrm{O}^{*}$ \\
\hline Cravo-da-índia & $100 \mu \mathrm{L} / 100 \mathrm{~mL}$ de $\mathrm{H}_{2} \mathrm{O}$ \\
\hline Eucalipto & $100 \mu \mathrm{L} / 100 \mathrm{~mL}$ de $\mathrm{H}_{2} \mathrm{O}$ \\
\hline \multicolumn{2}{|l|}{ Indutor de resistência } \\
\hline Acibenzolar-S-Metil & $0,05 \mathrm{~g} / 100 \mathrm{~mL}$ de $\mathrm{H}_{2} \mathrm{O}$ \\
\hline Fosfito & $300 \mu \mathrm{L} / 100 \mathrm{~mL}$ de $\mathrm{H}_{2} \mathrm{O}$ \\
\hline Acido salicílico & 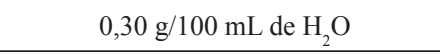 \\
\hline \multicolumn{2}{|l|}{ Antagonista } \\
\hline Bacilus subtilis & $100 \mu \mathrm{L} / 100 \mathrm{~mL}^{\mathrm{de}} \mathrm{H}_{2} \mathrm{O}$ \\
\hline Trichoderma sp. & $10^{8}$ conídios $/ \mathrm{mL}$ \\
\hline Levedura $I A 8$ & $10^{7} \mathrm{ufc} / \mathrm{mL}$ \\
\hline \multicolumn{2}{|l|}{ Anti-microbiano } \\
\hline Hipoclorito de sódio & $25 \mathrm{ml} / 100 \mathrm{ml} \mathrm{de} \mathrm{H}_{2} \mathrm{O}$ \\
\hline Dióxido de cloro & $100 \mu \mathrm{L} / 100 \mathrm{ml} \mathrm{de} \mathrm{H}_{2} \mathrm{O}$ \\
\hline Sorbato de potássio & $0,1 \mathrm{~g} / 100 \mathrm{ml}$ de $\mathrm{H}_{2} \mathrm{O}$ \\
\hline
\end{tabular}

${ }^{*} \mathrm{H}_{2} \mathrm{O}$ destilada e esterilizada em todos os casos.

bandejas plásticas ( 5 bananas/bandeja) sobre uma camada de papel de filtro ( 3 folhas) umedecidos com $100 \mathrm{~mL}$ de água destilada esterilizada, e incubados em sala de incubação à $28^{\circ} \mathrm{C} \pm 2^{\circ} \mathrm{C}$ no escuro. Doze horas após incubação, as bananas foram inoculadas com o patógeno, no mesmo poço no qual se instalou os tratamentos a serem testados, empregando-se uma suspensão de $C$. musae com concentração de 2,7 x $10^{4}$ conídios. $\mathrm{mL}^{-1}$ que foi preparada a partir de colônias do fungo cultivadas em BDA por 7 dias. Após a inoculação do patógeno, os frutos foram novamente incubados nas condições acima citadas por um período de 7 dias. Avaliaram-se o diâmetro das lesões desenvolvidas em cada banana e os resultados, expressos em percentagem em relação à testemunha de acordo com a seguinte fórmula: $\mathbf{P}=(\mathbf{D t}-\mathbf{D y}) \mathbf{x} \mathbf{1 0 0 /}$ Dt, onde Dt é o diâmetro médio da lesão do tratamento testemunha e Dy é o diâmetro médio obtido em cada tratamento. O experimento foi conduzido em delineamento inteiramente casualizado, com 5 repetições por tratamento. Cada unidade experimental foi composta por 5 bananas com 2 ferimentos cada. Os dados foram submetidos à análise de variância e as médias (diâmetro das colônias) comparadas pelo teste de Tukey a $5 \%$ de probabilidade por meio do programa ASSISTAT (40).

\section{RESULTADOS E DISCUSSÃO}

Verificação in vitro do efeito de extratos e óleos essenciais vegetais sobre Colletotrichum musae

Verificou-se que o tratamento com os extratos vegetais de alecrim pimenta e cravo-da-índia foram efetivos, equivalendo ao tratamento com fungicida que inibiu o crescimento micelial do patógeno em 100 $\%$, em todas as concentrações testadas $(5 \%, 10 \%, 15 \%, 20 \%, 25 \%$ e $30 \%$ ) (Figura 1). Contudo, nesses dois extratos, as concentrações empregadas não diferiram significativamente entre si ao nível de $5 \%$ de probabilidade. No tratamento com extrato de eucalipto, nas diferentes concentrações $(5 \%, 10 \%, 15 \%, 20 \%, 25 \%$ e $30 \%)$, verificouse inibição do crescimento micelial à medida que se aumentava a concentração do extrato, com valores percentuais de 37 \%, 52 \%, 69 $\%, 74 \%, 89 \%$ e $97 \%$, respectivamente.

A redução do crescimento micelial de patógenos, utilizando extratos de alecrim pimenta, foi constatada por diversos pesquisadores em vários patossistemas. Rozwałka et. al. (50) observou efeito inibitório nos extratos de alecrim e gengibre sobre o crescimento micelial de Glomerella cingulata e Colletotrichum gloeosporioides em frutos de goiabeira. $\mathrm{O}$ extrato bruto aquoso de alecrim pimenta demonstra elevado potencial para o controle alternativo da antracnose do cajueiro causada por Colletotrichum gloeosporioides (11).

$\mathrm{Na}$ forma de extrato e óleo, o cravo-da-índia apresentou grande eficiência como agente antimicrobiano, sugerindo-se que essa ação foi devida ao eugenol ou ao cariofileno ou a essas duas substâncias que são os principais constituintes dessa planta medicinal (3). Esses resultados foram confirmados por Costa et. al. (14) sobre o efeito de diferentes concentrações do extrato (2.000 e 3.000 ppm) na total inibição do crescimento micelial de Colletotrichum gloeosporioides, Pythium

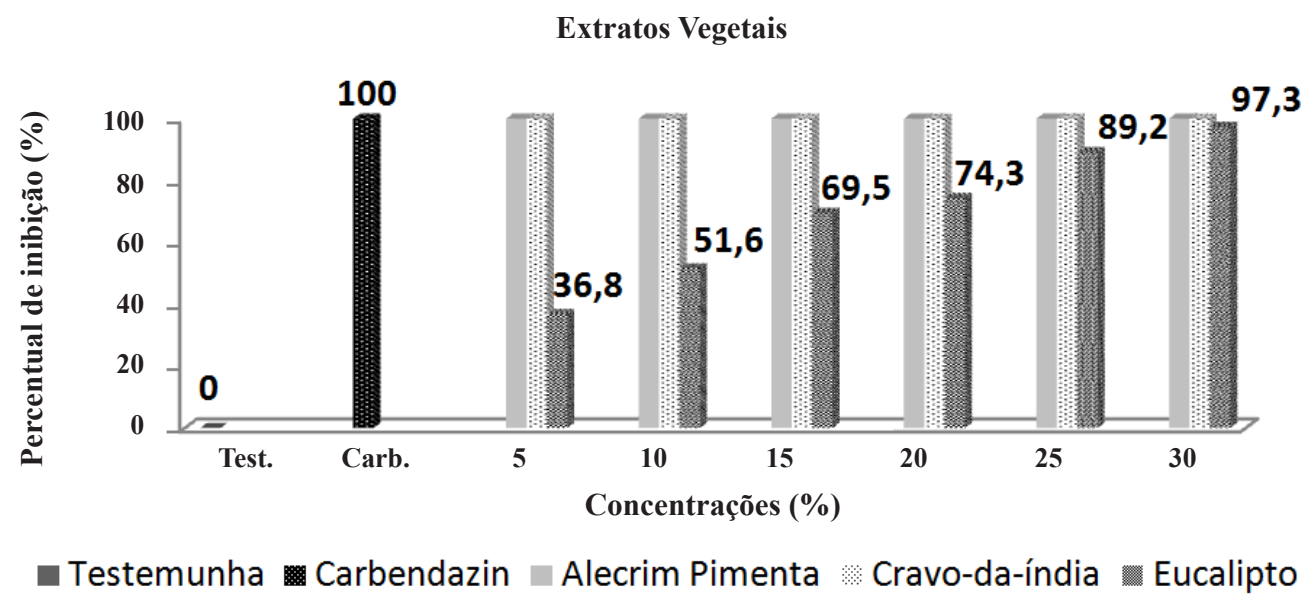

Figura 1. Efeito de extratos vegetais de alecrim pimenta, cravo-da-índia e eucalipto na inibição de C. musae in vitro. Médias seguidas da mesma letra não diferem entre si pelo teste de Tukey a $5 \%$ de probabilidade. 
periillum e Sclerotium rolfsii. O extrato aquoso de cravo-da-índia na concentração de $10 \%$ apresentou efeito fungitóxico inibindo $100 \%$ do crescimento micelial de Glomerella cingulata e Colletotrichum gloeosporioides (50).

Na Figura 2, pode ser observado o efeito dos três óleos essenciais testados (alecrim pimenta, cravo-da-índia e eucalipto) no crescimento micelial do fungo em estudo. Comparando-se as médias de crescimento micelial do patógeno, verificou-se que os óleos de alecrim pimenta e o de cravo-da-índia tiveram efeito inibitório semelhante aos dos extratos dessas mesmas plantas. No caso do cravo-da-índia, seu efeito inibidor foi igual ao do fungicida, ou seja, 100\%, em todas as 3 concentrações testadas $(25 \mu \mathrm{L}, 50 \mu \mathrm{L}$ e $100 \mu \mathrm{L})$.

Em relação ao alecrim pimenta, o efeito inibidor foi menor apenas à menor concentração, contudo, essa não diferiu estatisticamente das outras concentrações, as quais foram semelhantes à inibição exercida pelo fungicida. Quanto ao óleo de eucalipto, houve pouco efeito na inibição do crescimento do patógeno para todas as concentrações testadas. Não houve diferença estatística dessas concentrações com a testemunha.

Souza Júnior (44), estudando o efeito fungitóxico de óleos essenciais, observaram que, as espécies Lippia sidoides, Ocimum gratissimum, Lippia citriodora, Cymbopogon citratus inibiram em 100 $\%$ o crescimento micelial do Colletotrichum gloeosporioides.

Amaral (3), avaliando a ação antifúngica do óleo de cravo nas concentrações de $0,025 \%, 0,05 \%, 0,1 \%$ e $0,5 \%$, em amostras de sementes de soja, feijão, arroz e milho, obteve completa inibição da microbiota fúngica a partir de $0,025 \%$, exceto para amostras de arroz, cuja concentração mínima inibitória foi de $0,05 \%$.

\section{Atividade de microrganismos antagonistas sobre $C$. musae}

Com base nos resultados obtidos pode-se afirmar que ocorreram diferenças significativas entre os antagonistas testados quanto à capacidade de inibir o crescimento micelial de C. musae, quando comparados à testemunha. Trichoderma sp. e Bacillus subtilis apresentaram os melhores resultados com índices de inibição de 84 $\%$ e $74 \%$, respectivamente, não diferindo significativamente entre si pelo teste Tukey a $5 \%$ de probabilidade (Figura 3). Verificou-se que Trichoderma sp. teve um crescimento contínuo sobre o meio de cultura, inibindo o crescimento do patógeno observado pela zona de demarcação na área de encontro dos dois organismos.

Villalobos et. al. (49), trabalhando com vinte isolados de Trichoderma obtidos a partir de pomares localizados em três produtoras de manga no México, observaram que dezessete isolados de Trichoderma apresentaram pelo menos $67 \%$ de inibição de crescimento contra Colletotrichum gloeosporioides. Um membro do grupo, identificado como T. asperellum T8a, foi capaz de controlar $C$. gloeosporioides in vitro e in vivo.

Mahadtanapuk (28), testando a ação de três espécies dos bacilos (Bacillus licheniformis, Bacillus amyloliquefaciens e Bacillus subtilis) sobre a germinação de Colletotrichum musae, nas concentrações de $1 \times 10^{8}, 2 \times 10^{8}, 3 \times 10^{8}$ e $4 \times 10^{8}$ (ufc. $\mathrm{mL}^{-1}$ ) comprovou que, para as concentrações a partir de $2 \times 10^{8} \mathrm{ufc} / \mathrm{mL}$, todas as três espécies apresentaram um absoluto efeito inibitório $(100 \%)$ sobre a germinação de conídios em comparação ao controle (2\%).

Embora os mecanismos de ação dos antagonistas aqui avaliados não tenham sido determinados na presente pesquisa, supõe-se que substâncias micostáticas ou fungicidas difundíveis no meio possam estar envolvidas no processo de inibição, tendo em vista a redução significativa do crescimento de C.musae na presença dos mesmos.

\section{Atividade de indutores de resistência sobre $C$. musae}

$\mathrm{Na}$ Figura 4, pode-se observar a influência de cada indutor testado sobre o crescimento micelial de C. musae. Esperava-se que o indutor não tivesse efeito tóxico sobre o patógeno desafiante (9); contudo, verificou-se que tal premissa necessita ser revista, pois os três produtos exerceram algum efeito inibidor sobre esse patógeno, provavelmente em função da dose empregada.

Os produtos comerciais fosfito de potássio e ácido salicílico foram os mais efetivos na inibição do patógeno, com percentual de inibição de $91,8 \%$ e $100 \%$, diferindo significativamente da testemunha ao nível de $5 \%$ de probabilidade. O resultado para Acibenzolar-S-metil, embora considerado de baixa eficiência, mostrou-se superior à testemunha com $30 \%$ de inibição.

Lopes (26), ao avaliar a ação fungitóxica in vitro de diversos fosfitos ("Fitofós-Mg", "Phytogard Zn", "Phytogard K" e "Phytogard Ca") a 50

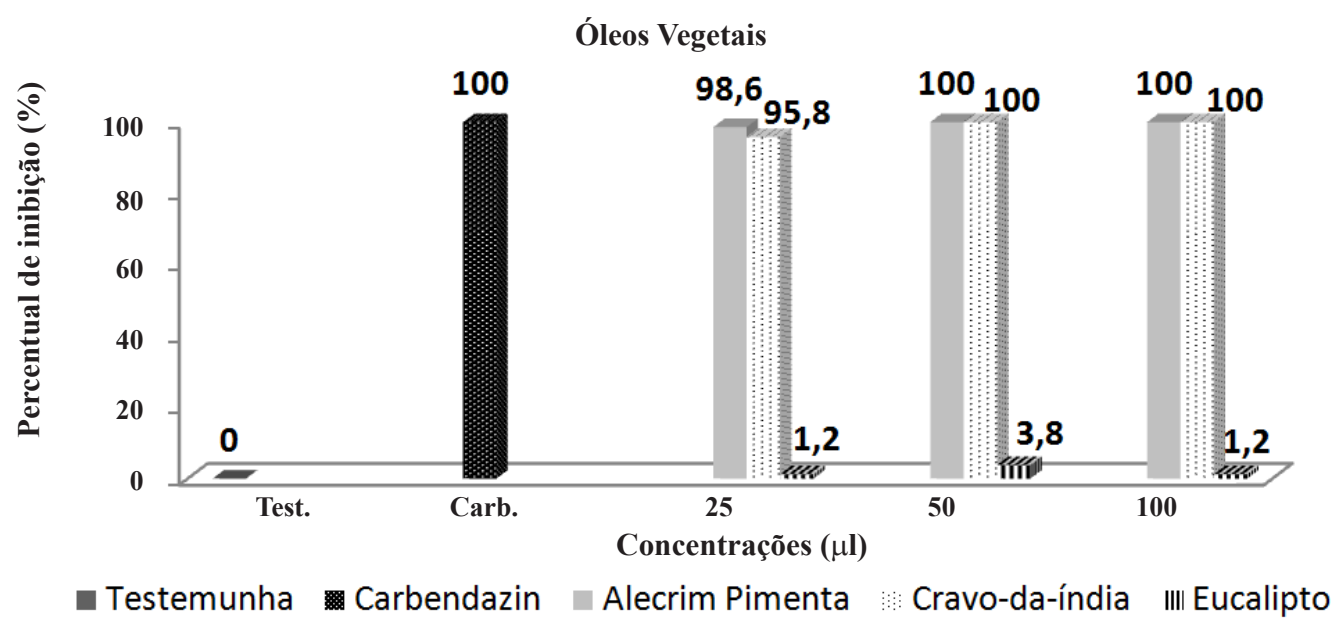

Figura 2. Efeito dos óleos vegetais de alecrim pimenta (AL), cravo-da-índia (CR) e eucalipto (EU) no controle de C. musae in vitro. Médias seguidas da mesma letra não diferem entre si pelo teste de Tukey a $5 \%$ de probabilidade. 
$\%, 100 \%$ e $200 \%$ da dose recomendada pelo fabricante, observou que eles foram eficientes na redução do crescimento micelial e na produção de conídios de C. gloreosporioides em todas as doses testadas.

Nojosa et. al.(34) relatam em seus trabalhos que o AcibenzolarS-Metil (ASM) e o fosfito de potássio inibiram em 56,23 \% e 62, 26 $\%$, respectivamente, o crescimento micelial de Phoma costarricensis Echandi em cafeeiro nas maiores doses testadas.

\section{Atividade de produtos anti-microbianos sobre $C$. musae}

$\mathrm{O}$ efeito de produtos químicos comumente empregados como sanitizantes foi testado no controle de C. musae. Observa-se, na figura 5, que dois desses tiveram ação antagônica sobre o crescimento micelial do fungo. Foram constatadas diferenças significativas entre o hipoclorito de sódio e o sorbato em comparação com a testemunha padrão. O hipoclorito de sódio destacou-se, tendo sido tão eficiente quanto o fungicida, com 100 $\%$ de inibição do crescimento do patógeno. O sorbato de potássio não foi tão eficiente quanto o hipoclorito de sódio e o fungicida carbendazin, mas diferiu significamente da testemunha com 65,8
\% de inibição de C. musae.

Observou-se que o dióxido de cloro não foi eficiente na inibição de C. musae. Confirmou-se a eficiente ação desinfestante promovida pelo hipoclorito de sódio, equivalente à do fungicida, na completa inibição do crescimento micelial do patógeno estudado.

A utilização do fungicida Carbendazin (3,3\%), álcool comercial (92,8 \%) e o uso do hipoclorito de sódio ( 2 \% PV) são agentes eficientes no controle de fungos e bactérias em explantes de bananeira; entretanto, ajustes nas concentrações e tempos de imersão dos explantes devem ser realizados (35).

Tavares et. al.(45) Comprovaram que o fungicida chlorotalonil e o hipoclorito de sódio apresentaram alto nível de eficiência inibindo $100 \%$ a germinação conidial do C. gloeosporioides.

\section{Estudos realizados 'in vivo'}

Atividade de extratos e óleos essenciais vegetais no controle da antracnose

O extrato de cravo-da-índia foi superior aos outros dois extratos e inferior ao tratamento químico, de acordo com o teste de Tukey a $5 \%$

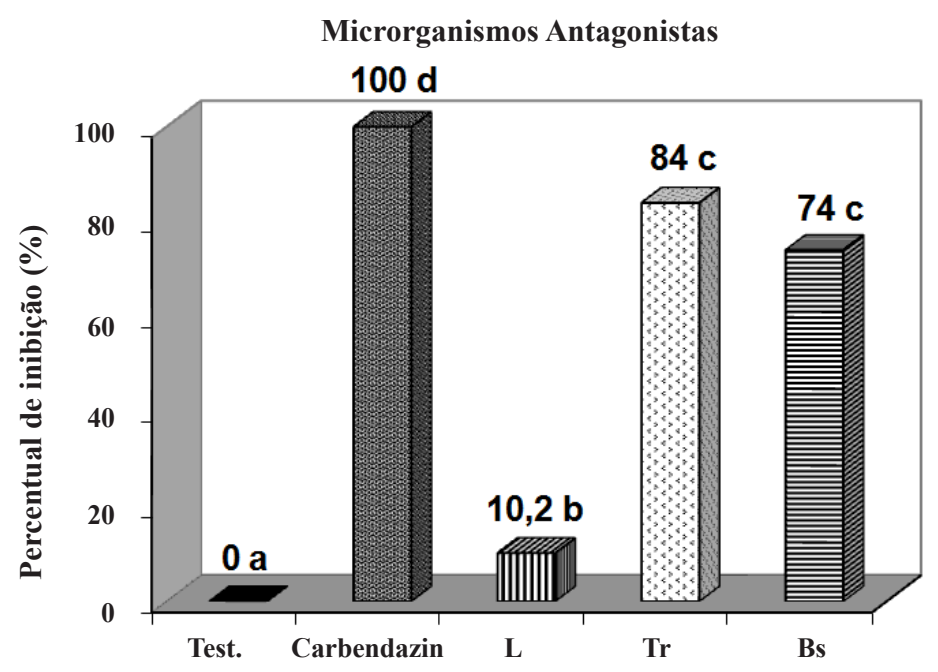

Figura 3. Efeito de antagonistas Levedura $I A 8$ (L),Trichoderma sp. (Tr) e B. subtilis (Bs) na inibição de C.musae in vitro. Médias seguidas da mesma letra não diferem entre si pelo teste de Tukey a $5 \%$ de probabilidade.

Indutores de Resistência

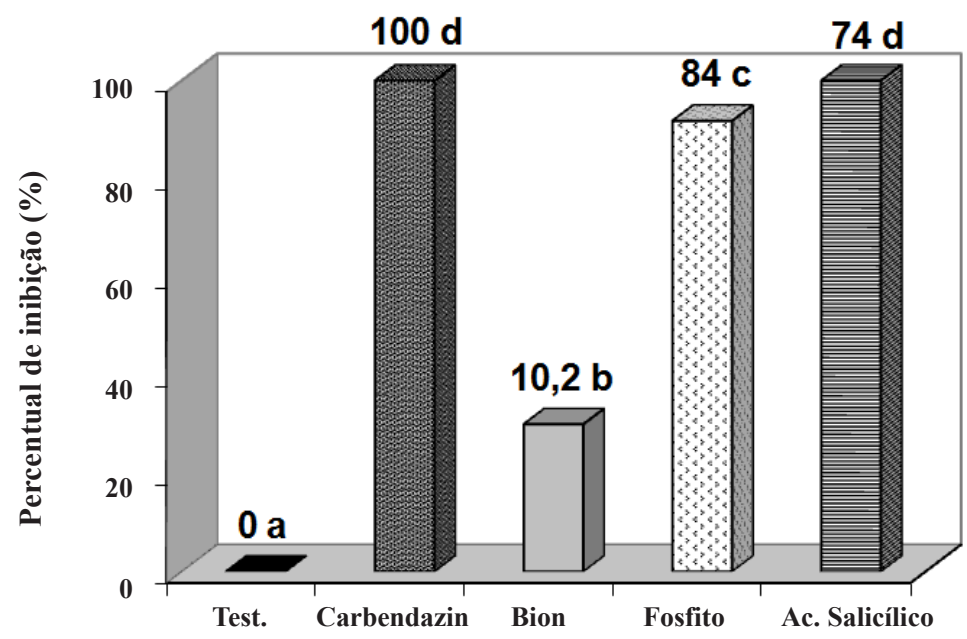

Figura 4. Efeito dos indutores de resistência Acibenzolar-S-Metil, fosfito de potássio e ácido salicílico no controle de C. musae in vitro. Médias seguidas da mesma letra não diferem entre si pelo teste de Tukey a $5 \%$ de probabilidade. 
de probabilidade (Figura 6).

Silva (41) avaliando a incidência do mal-do-panamá, em testes in vivo com extrato aquoso de cravo-da-índia, comprovou que esse extrato foi o mais efetivo no controle da doença, obtendo índice de doença de apenas $17,25 \%$.

Testes com extrato aquoso de eucalipto realizado por Rodrigues et. al. (39) comprovou atividade antifúngica sobre o fungo Helminthosporium sp. identificado nas fibras do pseudocaule da bananeira, tanto in vitro como in vivo. Aplicado preventivamente, em concentrações acima de $5 \%$, nas fibras de bananeira, o produto proporcionou controle total do patógeno.

Os óleos de alecrim pimenta e eucalipto foram os mais promissores, com inibição de $30 \%$ e $26 \%$ respectivamente, não diferindo significativamente entre si (Figura 7). Embora esses resultados tenham sido superiores àqueles obtidos pela testemunha são considerados ainda insatisfatórios quando comparados ao controle químico.

No tratamento com o óleo de cravo-da-índia verificou-se o completo escurecimento da casca dos frutos na maioria das repetições, possivelmente devido a uma atividade fitotóxica desse óleo na concentração testada. Bastos (7) ao avaliar o controle de C. musae em pós-colheita de banana constatou $100 \%$ de inibição pela aplicação de Piper aduncum nas concentrações de $100 \mu \mathrm{g} / \mathrm{ml}$ e $150 \mu \mathrm{g} / \mathrm{ml}$, respectivamente. $\mathrm{O}$ efeito do óleo no controle da podridão de frutos foi evidenciado através da redução da incidência e severidade da doença, em comparação com a testemunha.

Trabalhos com óleo de cravo e eucalipto sobre a incidência do Mal-do-Panamá em testes in vivo, apresentaram redução do índice da doença de $95,75 \%$ e $79 \%$, respectivamente (41).

\section{Atividade de microrganismos antagonistas sobre $C$. musae.}

O fungo Trichoderma sp. dos antagonistas utilizados mostrou-se o mais eficaz, com percentual de inibição da antracnose de $56 \%$, diferindo estatisticamente da média de inibição dos demais microrganismos testados e da testemunha, contudo, estatisticamente inferior ao fungicida, todos comparados ao nível de $5 \%$ de probabilidade pelo teste de Tukey (Figura 8).

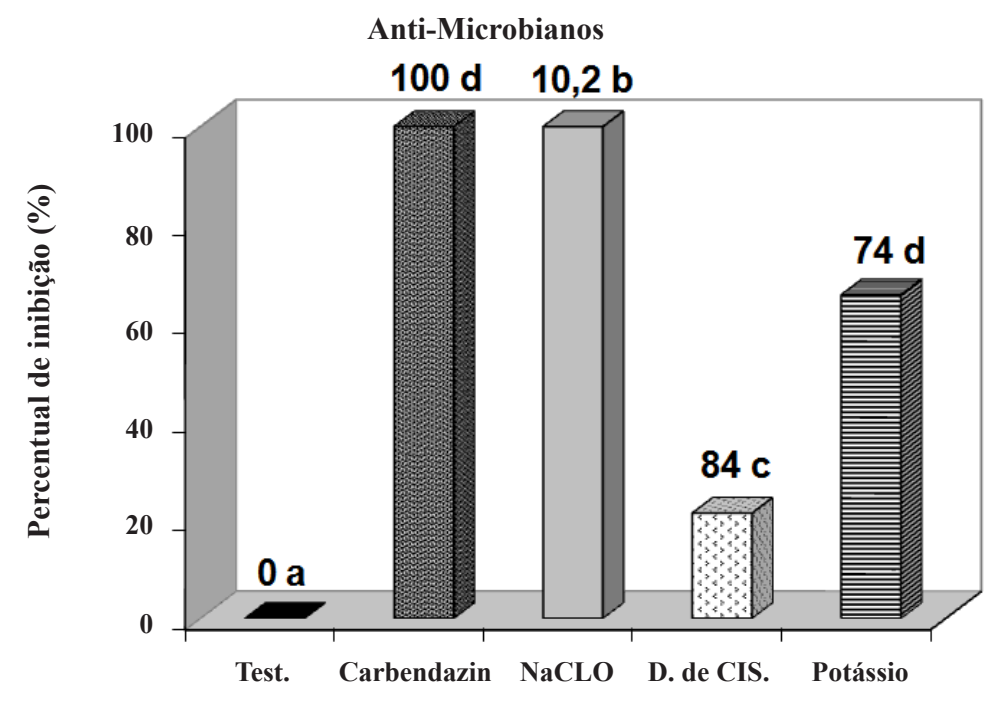

Figura 5. Efeito das substâncias anti-microbianas, hipoclorito de sódio, dióxido de cloro e sorbato de potássio no controle de C. musae in vitro. Médias seguidas da mesma letra não diferem entre si pelo teste de Tukey a $5 \%$ de probabilidade.

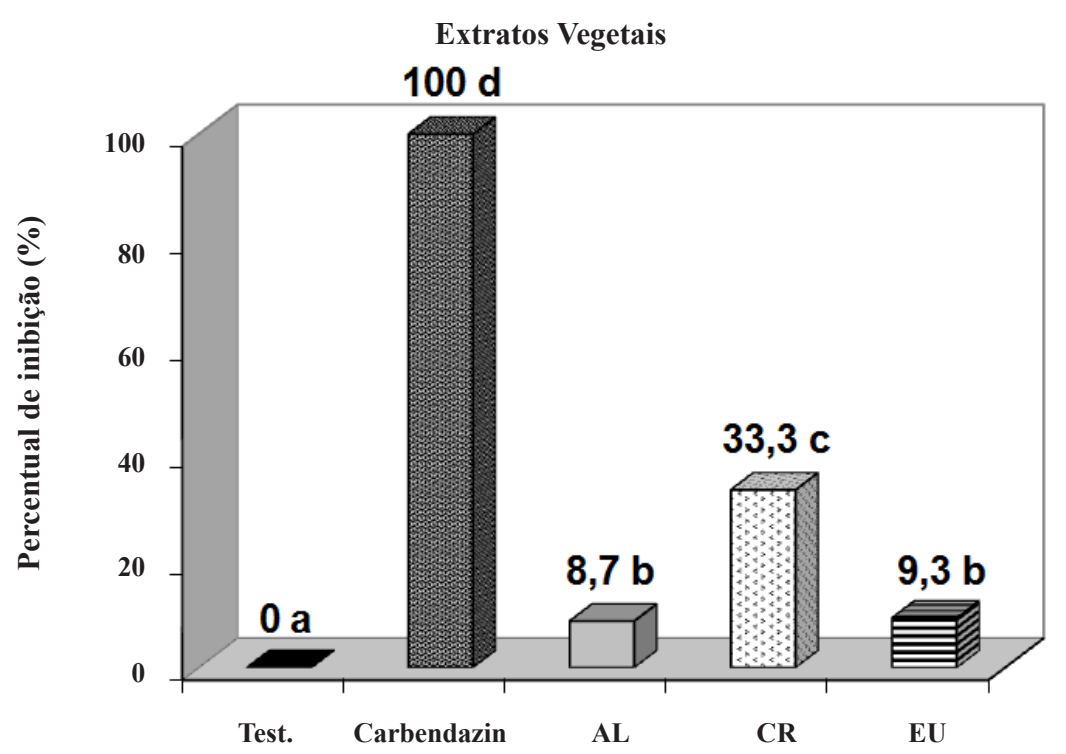

Figura 6. Efeito dos extratos de alecrim pimenta (AL), cravo-da-índia (CR) e eucalipto (EU) no controle da antracnose da banana in vivo. Médias seguidas da mesma letra não diferem entre si pelo teste de Tukey a $5 \%$ de probabilidade 
Freeman et. al. (22) demonstraram a possibilidade do emprego comercial de Trichoderma para o controle de Colletotrichum acutatum em morangos, tendo todas as concentrações testadas sido efetivas no controle do patógeno. Neste trabalho, o emprego de Trichoderma sp. demonstrou a viabilidade do emprego de formulações desse fungo antagônico para o controle da antracnose pós-colheita da banana.

Apesar dos relatos de sucesso, por diferentes autores $(23 ; 25)$, do emprego de leveduras killer no controle de fitopatógenos, os resultados obtidos neste trabalho para levedura foram considerados de baixa eficiência não diferindo significativamente da testemunha. E, embora Bacillus subtilis seja citado como antagônico de sucesso no controle de várias doenças, Korsten et. al. (24) já verificaram que esse microrganismo pode ter ação negativa também, pois elevou a podridão em frutos de abacate em nível acima do controle quando aplicado em pré-colheita.

A eficiência de bactérias do gênero Bacillus no controle de doenças de pós-colheita pode ser verificada no trabalho de Arrebola et. al. (5). Esses autores demonstraram que a aplicação de B. amyloliquefaciens (PPCB004) em frutos de laranja, 24 h antes ou depois da inoculação com os patógenos, apresentou controle diferenciado, variando com o patógeno. Para C. gloeosporioides, a aplicação, após a inoculação, apresentou melhor controle. Antoniolli et. al. (4) demonstraram que a aplicação em pré-colheita com B. amyloliquefaciens, em framboesa, 3, 7 e 14 dias antes da colheita, reduziu a incidência das podridões de Rhizopus e Botrytis, inoculados após a colheita, por até sete dias.

\section{Atividade de indutores de resistência sobre $C$. musae.}

Na Figura 9 verifica-se que o ácido salicílico foi estatisticamente igual ao Acibenzolar-S-Metil e fosfito e não houve diferença entre esses dois últimos. No entanto, o fosfito apresentou um percentual de inibição da doença de $28 \%$, mas muito inferior à ação do fungicida.

O potencial de utilização de indutores de resistência em pré e póscolheita de frutos são promissores na busca de produtos de melhor qualidade. Nascimento et. al. (31) controlou significativamente a podridão peduncular do mamoeiro com Acibenzolar-S-Metil reduzindo as perdas pós-colheita, o que não foi comprovado no presente trabalho, quando utilizamos o Acibenzolar-S-Metil no tramento dos frutos de banana. Segundo Cia (12), a aplicação em pré-colheita de Acibenzolar-

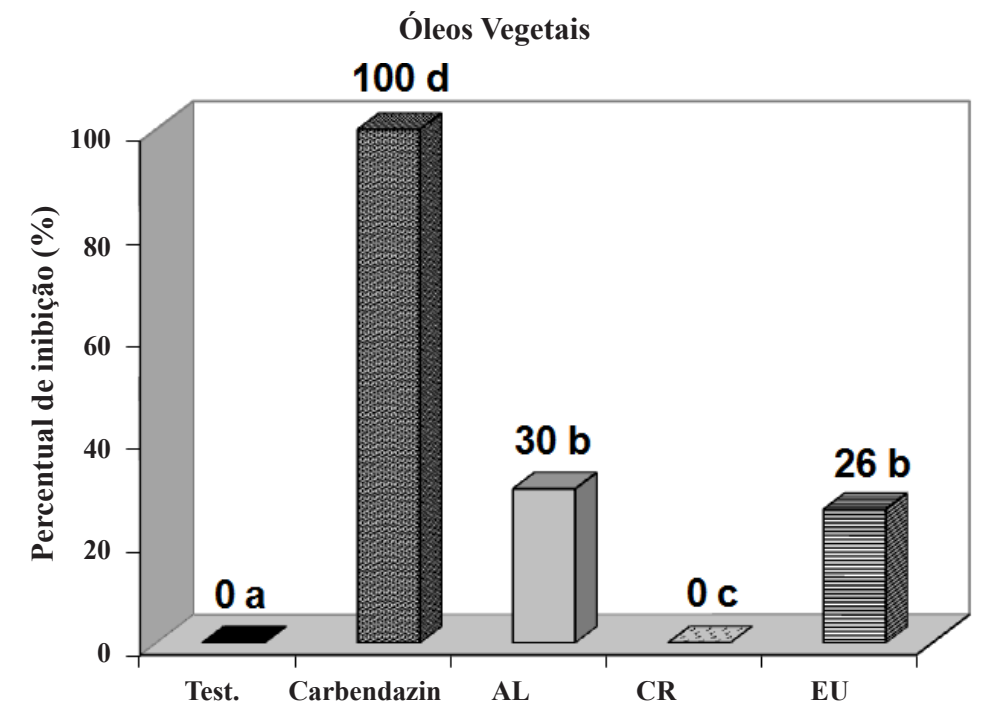

Figura 7. Efeito dos óleos de alecrim pimenta (AL), cravo-da-índia (CR) e eucalipto (EU) no controle da antracnose da banana in vivo. Médias seguidas da mesma letra não diferem entre si pelo teste de Tukey a $5 \%$ de probabilidade.

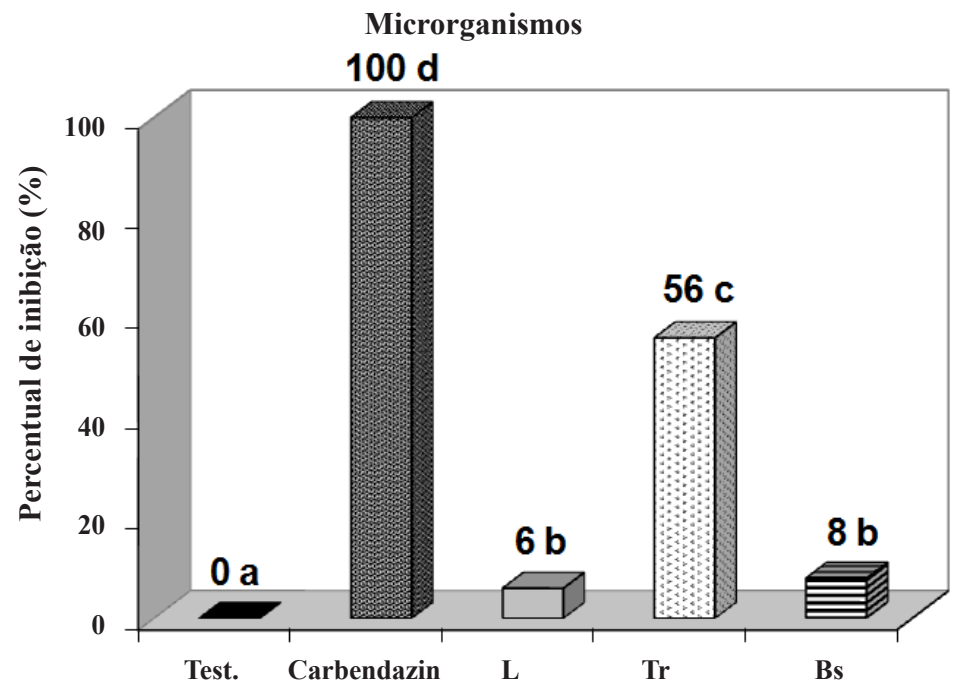

Figura 8. Efeito de microrganismos antagonistas Levedura IA8(L), Trichodermasp. (TR) e B. subtilis(Bs) no controle da antracnose da banana in vivo. Médias seguidas da mesma letra não diferem entre si pelo teste de Tukey a $5 \%$ de probabilidade. 
S-Metil em mistura com azoxistrobina, é eficiente na proteção dos frutos de mamoeiro em pós-colheita contra antracnose, reduzindo a incidência e a severidade da doença.

Vários estudos têm demonstrado a utilização do fosfito no controle de fitopatógenos em frutos. Dutra (17) constatou em seu trabalho com frutos de maracujazeiro que entre dez fosfitos diferentes, três (Fosfito K1, Fosfito K2 e Fosfito Zn) reduziram a severidade da antracnose em pós-colheita. Ferraz (20) demonstrou que o fosfito $\mathrm{Zn}$ e o fosfito $\mathrm{K}$ foram mais eficientes no controle do $C$. gloeosporioides em goiabas pós-colheita. As doses de 1,5 e 2,0 mL/L do fosfito $\mathrm{K}$ foram mais eficientes na redução do diâmetro das lesões e do número de lesões provenientes de infecção natural nos frutos.

Em estudos com o ácido salicílico (36), verificaram que morangos cultivar "Dover", submetidos aos tratamentos de choque térmico, aplicação de ácido salicílico e combinação de choque térmico com ácido salicílico não demonstraram ter efeito no controle de fungos.
Pereira (37) verificaram que os tratamentos com extratos vegetais, Acibenzolar-S-Metil e ácido salicílico proporcionaram menor eficiência no controle do míldio da videira, tanto em folhas quanto em cachos, com índices de doença inferiores apenas aos da testemunha.

\section{Atividade de substâncias antissépticas sobre $C$. musae.}

Neste teste podem-se observar diferenças estatísticas entre essas substâncias quanto à capacidade para inibir o crescimento micelial do patógeno. Entres elas, o Hipoclorito de sódio foi o que proporcionou maior ação antifúngica inibindo em 54 \% o crescimento do patógeno, sendo superior as demais substâncias e à testemunha, mas menos efetivo que o controle químico, a $5 \%$ de probabilidade (Figura 10). O hipoclorito de sódio ( $2 \% \mathrm{PV})$ é considerado um agente eficiente no controle de fungos e bactérias em explantes de bananeira; embora, ajustes nas concentrações e tempos de imersão dos explantes devam ser realizados $(33)$.

\section{Indutores de Resistência}

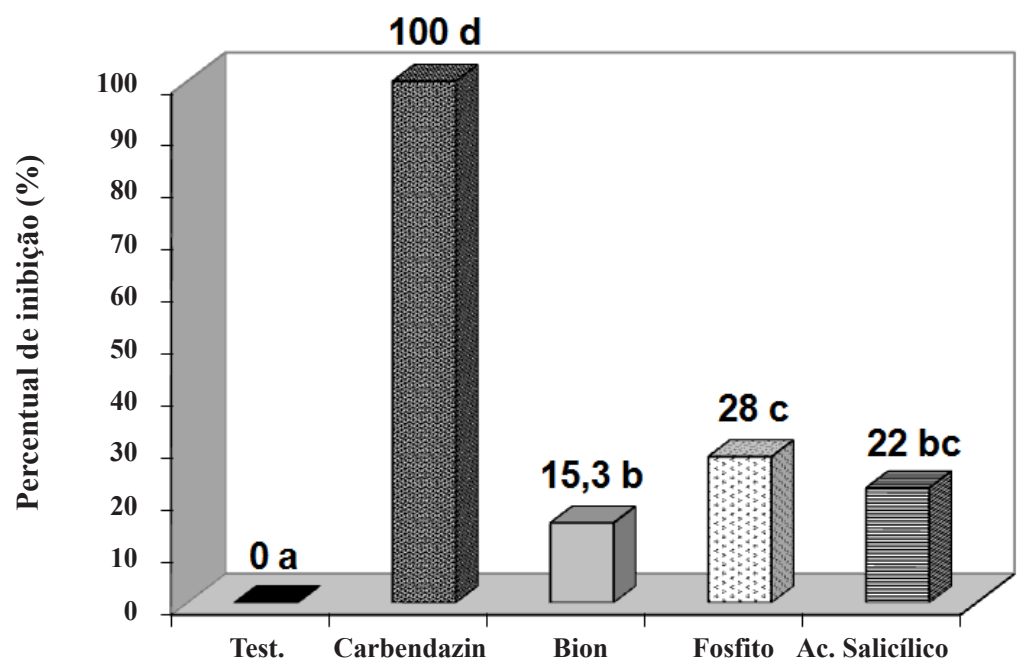

Figura 9. Efeito dos indutores de resistência Acibenzolar-S-Metil, fosfito e ácido salicílico no controle da antracnose da banana in vivo. Médias seguidas da mesma letra não diferem entre si pelo teste de Tukey a $5 \%$ de probabilidade.

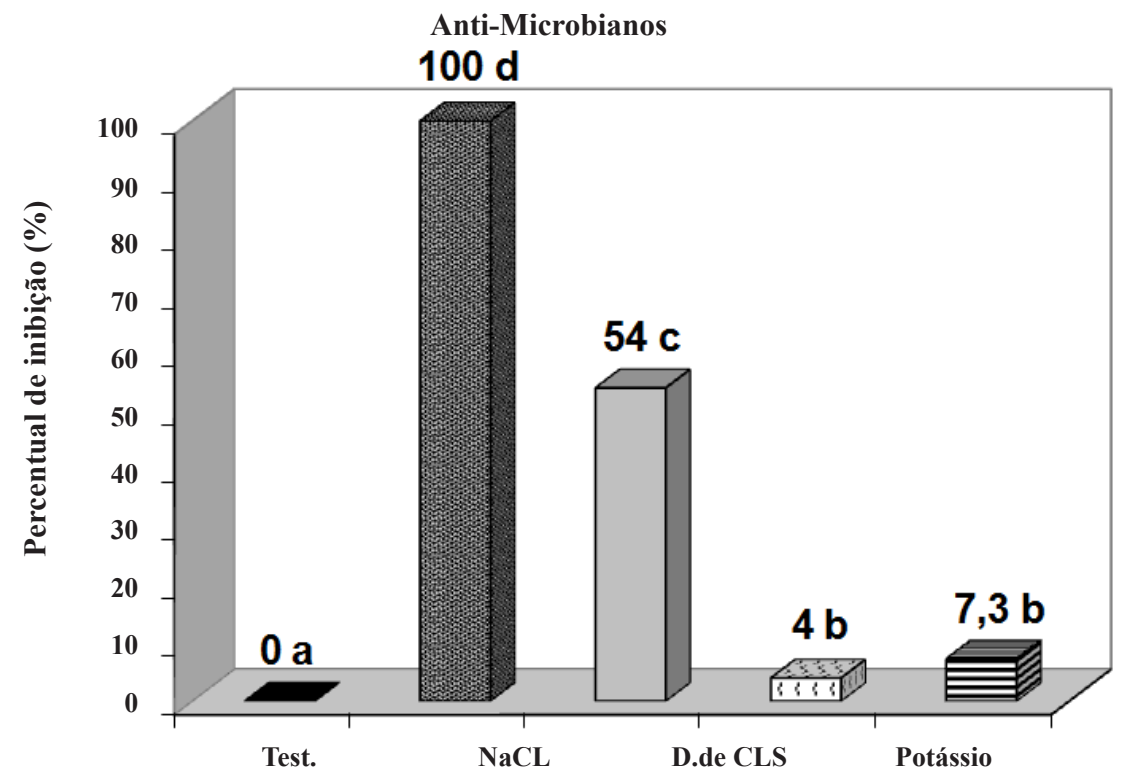

Figura 10. Efeito das substâncias anti-microbianas hipoclorito de sódio, dióxido de cloro e sorbato de potássio no controle da antracnose da banana in vivo. Médias seguidas da mesma letra não diferem entre si pelo teste de Tukey a $5 \%$ de probabilidade. 
Segundo Fischer et. al. (21), o controle pós-colheita da antracnose em abacate foi verificado com cloreto de benzalcônio, dióxido de cloro e tiabendazol, no décimo dia de armazenamento. Entretanto, assim como os tratamentos com azoxistrobina, Ecolife ${ }^{\circledR}$ e hipoclorito de sódio, não foram eficientes em reduzir a incidência da antracnose, nas avaliações subsequentes.

No estudo da refrigeração associada à sanitização no controle integrado da podridão em melão, o dióxido de cloro contribuiu de maneira eficiente no controle de Fusarium pallidoroseum, reduzindo em $54 \%$ a incidência e a severidade da doença, quando associado à refrigeração (46).

Trabalhos in vivo com sorbato de potássio visando o controle de Penicillium em pós-colheita em citros demonstraram que na concentração de 10.000 g.mL $\mathrm{mL}^{-1}$ reduziu em $51 \%$ a incidência da doença (19).

A baixa eficiência do controle de C. musae in vivo pode ser atribuída à baixas concentrações dos produtos testados, bem como a volatilidade daqueles de origem vegetal. De acordo com Silveira et. al. (43), as tentativas de controle de doenças pós-colheita em frutas, sem o conhecimento suficiente sobre os patógenos, pode levar a pouca ou nenhuma redução do problema havendo, portanto, a necessidade de estudos epidemiológicos envolvendo estas doenças que permitam maior entendimento dos patossistemas, bem como fornecer subsídios importantes para o desenvolvimento de estratégias de manejo. Também Silva (42), sugere que muitos dos problemas pós-colheita originam-se em pré-colheita, determinando o insucesso dos tratamentos aplicados no estágio de pós-colheita. Tais considerações justificam a baixa eficiência da maioria dos tratamentos nos testes in vivo, no controle da antracnose em frutos de banana. Uma vez que o C. musae agente causal da doença pode infectar os frutos em etapas anteriores do cultivo, instalando-se ainda no campo, na camada subcuticular sob a forma de infecção quiescente, concordante com relato de Moraes et. al. (30).

É de vital importância o direcionamento de estudos que tenham como finalidade o desenvolvimento de medidas de controle que minimizem o uso de agrotóxicos, adequando-se às normas de controle ambiental, qualidade do produto e qualificação dos trabalhadores envolvidos na cadeia produtiva. O emprego in vivo de antagonistas, indutores de resistência, substâncias antissépticas, de extratos e óleos essenciais, exceto óleo de cravo, embora não apresentando resultados consistentes na inibição do desenvolvimento de lesões em bananas, não induziu fitotoxicidade. Com base nisso sugere-se a avaliação de novas técnicas, épocas, doses e intervalos de aplicação na busca por alternativas não poluentes, atóxicas ou não residuais para tratamento da antracnose sobre frutos de banana em pré-colheita, o que possibilitará a identificação de um método seguro e eficaz no controle do patógeno. Somente com a adoção dessas medidas, que devem iniciar no campo e se estender até ao consumidor final, será possível atingir os parâmetros de qualidade exigidos pelo mercado.

Nos testes in vitro os extratos e óleos essenciais vegetais de alecrim pimenta e cravo-da-índia, os produtos fosfito de potássio, o ácido salicílico e o hipoclorito de sódio reduziram o crescimento do patógeno em $100 \%$.

Nos testes in vivo apenas o antagonista Trichoderma sp. e o hipoclorito de sódio reduziram a antracnose (C. musae) em banana em mais de $50 \%$.

\section{REFERÊNCIAS}

1. Agricultura Rural. Disponível em: <http://agricultura.ruralbr.com.br/ noticia/2013/07/ministerio-quer-barrar-importacao-de-banana-do-equador-4198547.html>. Acesso em: 17 nov. de 2013.

2. Alfenas, A.C.;Ferreira, F.A.; Mafia, R.G.; Gonçalves, R.C. Métodos em Fitopatologia. Edição: Alfenas, A.C.; Mafia, R.G. Cap. Isolamento de Fungos Fitopatogênicos. p.53-90.2007.

3. Amaral, M.F.Z.J. Avaliação da atividade antifúngica de extratos de plantas sobre o crescimento de fitopatógenos. Revista Eletrônica de Farmácia, Suplemento, v. 2 n. 2, p. 5-8, 2005.

4. Antoniolli, L.R.; Silva, G.A.; Alves, S.A. M.; Moro, L. Controle alternativo de podridões pós-colheita de framboesas. Pesquisa Agropecuária Brasileira, Brasília, v. 46, n. 9, p. 979-984, 2011.

5. Arrebola, E.; Jacobs, R.; Korsten, L. Iturin A is the principal inhibitor in the biocontrol activity of Bacillus amyloliquefaciens PPCB004 against postharvest fungal pathogens. Journal of Applied Microbiology, Oxford, v. 108, n. 2, p. 386-395, 2010.

6. Athayde Sobrinho, C.; Ferreira, P.T. de; Cavalcanti, L.S. Indutores abióticos. In: Cavalcanti, L.S.; Di Piero, R.M.; CIA, P.; Pascholati, S.F.; Resende, M.L.V. de; Romeiro, R.S. Indução de resistência em plantas a patógenos e insetos. Piracicaba: FEALQ, v. 13, p. 51-80, 2005.

7. Bastos, C.N.; Albuquerque, P.S.B. Efeitos do óleo de Piper aduncum no controle em pós-colheita de Colletotrichum musae em banana. Fitopatologia Brasileira, Marituba, PA. v. 29, n. 5, p. 555-557, 2004.

8. Bettiol, W.; Morandi, M.A.B. (Ed.). Biocontrole de doenças de plantas: uso e perspectivas. Jaguariúna: Embrapa Meio Ambiente, 341 p, 2009.

9. Bonaldo, S.M.; Pascolathi, S.F.; Romeiro, S.R. Indução de resistência: noções básicas e perspectivas. In: Cavalcanti, L.S.; Di Piero, R.M.; CIA, P.; Pascolathi, S. F.; Resende, M.L.V.; Romeiro, R.S. Indução de resistência em plantas a patógenos e insetos. Piracicaba: FEALQ, p.11-28. 2005.

10. Campos Silva, J.R.; Souza, R.M.; Zacarone, A.B.; Silva, L.H.C.P.; Castro, A.M.S. Bactérias endofiticas no controle e inibição in vitro de Pseudomonas syringae pv. tomato, agente da pinta bacteriana do tomateiro. Ciência e Agrotecnologia, Lavras, v.32, p.1062-1072, 2008.

11. Carvalho, P.R.S.; Barreto, M.; Camargo, M. Extratos vegetais: potencial elicitor de Fitoalexinas e atividade antifúngica em Antracnose do cajueiro. 2010. 51f. Tese (Doutorado em Agronomia/Produção Vegetal)- Faculdade de Ciências Agrárias e Vterinárias- Unesp, Jaboticabal - São Paulo.

12. Cia, P. Avaliação de agentes bióticos e abióticos na indução de resistência e no controle pós-colheita de antracnose (Colletotrichum gloeosporioides) em mamão (Carica papaya). 2005. 197f. Tese (Doutorado em Agronomia/Fitopatologia). Escola Superior de Agricultura Luiz de Queiroz-ESALQ, Piracicaba.

13. Couto, E.F.E.; Menezes, M. Caracterização fisiomorfológica de isolados de Colletotrichum musae. Fitopatologia Brasileira, Brasília, v.29, n.4 p.406-412, 2004.

14. Costa, R.C.; Poltronieri, L.S.; Pereira, D.R.S.; Souza, A.C.; Santos, I.P.; Fecury, M.M.; Xavier, J.R.M. Sensibilidade in vitro de óleos essenciais no controle de Corynespora cassiicola. In: Congresso Brasileiro de Defensivos Agrícolas Naturais, 2006, Belém-PA. Anais. Belém: Embrapa Amazônia Oriental, p.35. 2006.

15. Cunico, M.M.; Carvalho, J.L.S.; Andrade, C.A.; Miguel, O.G. Miguel, M.D.; Auer, C.G.; Grigoletti Júnior, A.; Côcco, L.C.; Yamamoto, C.I. Atividade antifúngica de extratos brutos de Ottonia martiana Miq., Piperaceae. Visão Acadêmica, Curitiba, v.7, p.15-24, 2006.

16. Del Ponte, E. M. (Ed.) Fitopatologia.net - herbário virtual. Departamento de Fitossanidade. Faculdade de Agronomia, UFRGS. Disponível em: $<$ http://www.ufrgs.br/agronomia/ fitossan/ herbariovirtual $>$. Acesso em: 02 de outubro. 2013

17. Dutra, J.B. Controle da antracnose (Colletotrichum gloeosporioides) póscolheita do maracujá-amarelo (Passiflora edulisf.flavicarpa) por aplicações de fosfitos, água quente e 1-metilciclopropeno.2008. 151f., Dissertação (Mestrado em Fitopatologia)- Universidade de Brasília, Brasília.

18. FAOSTAT. Food and Agriculture Organization of the United Nations. Top production, Brasil, 2011. Disponível em: $<\mathrm{http} / /$ faostat.fao.org/site $>$. Acesso em: 8 agosto, 2013.

19. Franco, D.A.S.; Bettiol, W. Eficiência do método do flavedo para avaliar a germinação de conídios de Penicillium digitatum, agente causal do bolor verde dos frutos cítricos. Summa Phytopathologica, São Paulo, v.26, n.2, 
p.265-268, 2000.

20. Ferraz, D.M.M. Controle da antractose (Colletotrichum gloeosporioides) em pós-colheita da goiaba (Psidium guajava), produzida em sistema de cultivo convencional e orgânico, pela aplicação de fosfitos, hidrotermia e cloreto de cálcio. 2010, 103f. Dissertação (Mestrado em Fitopatologia)Universidade de Brasília, Brasília.

21. Fischer, I.H.; Tozze Júnior, H.J.; Arruda, M.C.; Massola Júnior, N.S. Póscolheita de abacates 'Fuerte' e 'Hass': aracterísticas físicas e químicas, danos e controle de doenças. Semina: Ciências Agrárias, Londrina, v. 32, n. 1, p. 209-220, jan./mar. 2011

22. Freeman, S.; Minz, D.; Kolesnik, I.; Barbul, O.Z.A.; Maymon, M.; Nitzani, Y.; Kirshner, B.; Ravi-David, D.; Bilu, A.; Dag, A.; Shafi, S.; Eladi, Y. Trichoderma biocontrol of Colletotrichum acutatum and Botrytis cinérea and survival in strawberry. European jornal of plant pathology, Bet Dagan, v.110, p.361-370, 2004.

23. Kefialewa, Y., Ayalewb, A. Postharvest biological control of anthracnose (Colletotrichum gloeosporioides) on mango (Mangifera indica). Postharvest Biology And Technology, Haramaya, Etiópia.v.50, p.8-10. 2008.

24. Korsten, L.; de Villiers, E.E.; Wehner, F.C.; Kotzé, J.M. Field sprays of Bacillus subtilis and fungicides for control of preharvest fruit diseases of avocado in South Africa. Plant Disease, St. Paul, v.81, p.455-459, 1997.

25. Lima, J.R.de; Viana, F.M.P.; Lima, A.; Lima, J.S.; Pieniz, V.; Gonçalves, L.R.B. Biocontrole da antracnose pós-colheita do mamão com levedura killer. Fortaleza: Embrapa Agroindústria Tropical. (Boletim de Pesquisa e Desenvolvimento, 59). 2012.

26. Lopes, L. F. Efeitos de aplicações pós-colheita de fosfitos, ácido acetilsalicílico e 1-metilciclopropeno sobre a antracnose do mamoeiro. 82 f. Dissertação (Mestrado em Fitopatologia) - Universidade de Brasília, Brasília. 2008.

27. Lucon, C.M.M. Trichoderma no controle de doenças de plantas causadas por patógenos de solo. Centro de Pesquisa e Desenvolvimento de Sanidade Vegetal. São Paulo. Instituto Biológico. Comunicado Técnico, 77.2008. Disponível emhttp://www.biologico.sp.gov.br/ artigos_ok.php?id_artigo=77, Acesso em 30 ago.2013.

28. Mahadtanapuk, S.; YU, L.D.; Cutler, R.; Vilaithong, T.; Anuntalat bhochar, S. Mutation of Bacillus licheniformis using low-energy ion bean bombardmet. Surface Coatings Technology, Tailândia, v.201, p. 8028-8033.2007.

29. Mariano, R. L. R. Métodos de seleção “in vitro” para controle microbiológico. Revisão Anual de Patologia de Plantas, Passo Fundo, v. 1, p. 369-409, 1993.

30. Moraes, W.daS.; Zambolim, L.; Lima, J.D. Incidência de fungos pós-cos lheita de banana "Prata anã"(Musae AAB). Summa Phytopathologia, Botucatu, v.32, n.1, p.67-70.2006.

31. Nascimento, L.; Nery, A.; Rodrigues, L. Controle de Colletotrichum gloeosporioides em mamoeiro, utilizando extratos vegetais, indutores de resistência e fungicida. Acta Scientiarum Agronomy, Maringá. v.30,p.313-319.2008

32. Negreiros, R.J.Z.de; Salomão, L.C.C.; Pereira, O.L.; Cecon, P.R.; Siquei ra, L.D. Controle da antracnose na pós-colheita de bananas-'prata' com produtos alternativos aos agrotóxicos convencionais. Revista Brasileira Fruticutulra. Jaboticabal. vol.35, n.1, p.51-58.2013.

33. Nietsche, S.; Marques, S.V.; Pereira, M.C.T.; Salles, B.; Xavier, A.A; França,A.C.; de Lima, C.; Silva,L.S. Estabelecimento in vitro de explantes de três cultivares de bananeira. Ciência Rural, Santa Maria, v.36, n.3, p.989-991.2006.

34. Nojosa, G.B.A.; Resende, M.L.V., Barguil, B.M.; Moraes, S.R.G.; Vilas Boas, C.H. Effect of resistance inducers on coffee against Phoma leaf spot.
Summa Phytopathologica, Botucatu. v.35, n.1, p.60-62.2009.

35. Oliveira, S.M.A.; Dantas, S.A.F.; Gurgel, L.M.S. Indução de resistência em doenças pós-colheita em frutas e hortaliças. Revisão Anual de Patologia de Plantas, Passo Fundo, v.12, p.343-371.2004.

36. Pazdiora, P.C.; Coltro, S.; Broetto, L.; Ravagnani, L.K.; Dildey, O.D.F.; Braga, G.C. Tratamento Térmico e Ácido Salicílico no Controle de Doenças Pós-Colheita de Morangos. Tropical Plant Pathology Manaus, v.38, n.433.2012. Suplemento.

37. Pereira, V.F.; Resende, M.L. V.; Monteiro, A.C. A.; Júnior, P.M.R.; Regina, M. A.; Medeiros, F.C.L. Produtos alternativos na proteção da videira contra o míldio. Pesquisa agropecuária brasileira, Brasília, v.45, n.1, p.25-31, jan. 2010 .

38. Querino, C.M.B.; Laranjeira, D.; Coelho, R.S. B.; Matos, R.P. de. Efeito de Dois Indutores de Resistência sobre a Severidade do Mal-do-Panamá. Fitopatologia Brasileira, v.30, p.239-243, 2005.

39. Rodrigues, A.A. C.; Bezerra N.; Coelho, R.S. B. Indução de Resistência a Fusarium oxysporum f. sp. Trapchei philumem caupi: eficiêcia, de indutores abióticos e aticidade enzimática elecitada. Fitopatologia Brasileira, v.31, n.5, p.492-499, 2006.

40. Silva, F.A.S.; Azevedo, C.A.V. Versão do programa computacional ASSIS TAT para o sistema operacional Windows. Revista Brasileira de Produtos Agroindustriais, Campina Grande, v.4, n.1, p.71-78, 2002.

41. Silva, J.C. Uso de óleos essenciais, extratos e indutores de resistência no controle alternativo do mal-do-Panamá da bananeira. 2007. 66f. Dissertação (Mestrado em Agronomia; Produção Vegetal; Proteção de Plantas)- Universidade Federal de Alagoas, Rio Largo.

42. Silva, F.C.da. Efeito in vitro e in vivo dos óleos essenciais sobre fungos que ocorrem em pós-colheita em frutos de morango e mamão. $85 \mathrm{f}$. Dissertação (Mestrado em Fitopatologia). Universidade Federal de Lavras, Lavras. 2008.

43. Silveira, N.S.S.da; Michereff, S.J.; da Silva, I.L. do S.S; Oliveira, S.M.A.de. Doenças fúngicas pós-colheita em frutas tropicais: patogênese e controe le. Caatinga. Mossoró, v.18, n.4, p.283-299, out./dez, 2005.

44. Souza Júnior, I.T.; Sales, N.L.P.; Martins, E.R. Efeito fungitóxico de óleos essenciais sobre Colletotrichum gloeosporioides, isolado do maracujazeiro amarelo. Revista Biotemas, Pelotas, v.22, n.3, p.11-83, 2009.

45. Tavares, G.M.; Souza, P.E. Efeito de fungicidas no controle in vitro de Colletotrichum gloesporiodes, agente etiológico da antracnose do mamoeiro ( $\mathrm{Ca}$ rica papaya l.)de Ciênc. agrotec., Lavras, v.29, n.1, p.52-59, jan./fev. 2005.

46. Terao, D.; Oliveira, S.A.de; Viana, F.M.P.; Gondim, D.F. Refrigeração ase sociada à sanitização no controle integrado da podridão em melão. Revista Caatinga, Mossoró, v.20,n.3, p.121-128.2007.

47. Valdebenito-Sanhueza, R.M.; Cattanio, M.E. Controle biológico de Penicillium expansum em pós colheita de maçãs 'Fuji'. Fitopatologia Brasileira, Jabuticabal, v.26, p.445. 2001.

48. Ventura, J.A.; Hinz, R.H. Controle das doenças da bananeira. In: Zambolim, L.; Vale, F.X.R.Do; Monteiro, A.J.A.; Costa, H. (Ed.). Controle de doenças de plantas fruteiras, Viçosa-MG: UFV, v.1, p.839-938.2002.

49. Villalobos, S. S.; Ortiz, D. A. G.; Lim, M. A. G.; Frier, J. P. D.; Folter, S.; García, P. S.; Cabriales, J. J. P. Potential use of Trichoderma asperellum (Samuels, Liechfeldt et Nirenberg) T8a as a biological control agent against anthracnose in mango (Mangifera indica L.). Biological Control. Guanajuato, México, v.64. p.37-44.2013.

50. Rozwałka, L.C.; Lima, M.L.R.Z.DaC.; Mio, L.L.M. de; Nakashima, T. Extratos, Óleos Essenciais e decoctos de Plantas Medicinais e Aromáticas na Inibição de Glomerella cingulata e Colletotrichum gloeosporioides de frutos de goiaba. Ciências Rural. Santa Maria, v.38, n.2, p 301-307.2008. 